\title{
Inventarisasi Konsep Ekosistem Pariwisata Dalam Pengembangan Destinasi Wisata Berkelanjutan: Kasus Waduk Walahar, Kabupaten Karawang
}

\author{
Vincent Sylvester Leewellyn ${ }^{\mathrm{a}, 1}$, Fitri Abdillah ${ }^{\mathrm{b}, 2}$

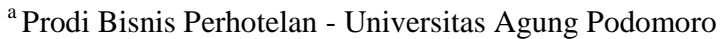 \\ ${ }^{\mathrm{b}}$ Prodi Bisnis Perhotelan - Universitas Agung Podomoro \\ ${ }^{1}$ vincent.sylvester@ podomorouniversity.ac.id; ${ }^{2}$ fitri.abdillah@ $@$ podomorouniversity.ac.id
}

\section{ARTICLE INFO}

Article history

Received

Revised

Accepted

Keywords

Tourism Ecosystem

Culinary Tourism Destination

Tourism Atraction

\begin{abstract}
Development in tourism supposed to be development of tourism destinations. There are three main components of tourism destinations that play an important role in the development, which are: tourists, local people (hosts), and the destination itself. This study was designed to record the components of the tourism ecosystem in the Walahar Tourism Destination, Karawang Regency. Walahar is known as a culinary destination in Karawang Regency. This research is expected to produce a model for developing sustainable culinary tourism destinations. The research was compiled with a preliminary stage compiling a profile of all tourism potentials, attractions, and gastronomic tourism products, and the level of readiness of the local community, in the study area. The expected research result is the inventory of the ecosystem components involved in the Walahar culinary destination. The identification of the tourism subsystem in Walahar Village shows that only one of the twelve subsystems qualifies as a tourism destination. Therefore the development of Walahar as a tourism destination requires government's effort. The development of Walahar as a destination also seems to be a solution to improve the quality of the environment by improving sanitation and environmental hygiene.
\end{abstract}

\section{Pendahuluan}

\subsection{Latar Belakang}

Undang-Undang No 10 Tahun 2009 mengamanatkan bahwa kepariwisataan merupakan bagian integral dari pembangunan nasional yang dilakukan secara sistematis, terencana, terpadu, berkelanjutan, dan bertanggung jawab. Pembangunan kepariwisataan juga harus tetap memberikan perlindungan terhadap nilai-nilai agama, budaya yang hidup dalam masyarakat, kelestarian dan mutu lingkungan hidup, serta kepentingan nasional. Untuk itu maka pembangunan kepariwisataan diarahkan untuk mendorong pemerataan kesempatan berusaha dan perolehan manfaat bagi masyarakat serta mampu menghadapi tantangan perubahan kehidupan lokal, nasional, dan global.

Pembangunan pariwisata sejatinya merupakan pembangunan destinasi pariwisata. Terdapat tiga komponen pokok destinasi pariwisata yang berperan penting dalam pembangunan tersebut, yaitu wisatawan (guest), masyarakat lokal (host), dan destinasi itu sendiri. Sebagai sebuah destinasi wisata, Indonesia mengandalkan tiga jenis daya tarik sebagai modal dasar untuk meningkatkan kunjungan wisatawan, yaitu daya tarik budaya, daya tarik alami, dan daya tarik buatan. Saat ini, industri pariwisata tidak hanya merupakan industri dengan pertumbuhan tertinggi, namun juga membawa perubahan ekonomi yang signifikan bagi dunia.

Saat ini pariwisata tidak bisa dilepaskan dengan kuliner/gastronomi. UNWTO (2017) menyatakan bahwa diperkirakan 30\% dari pendapatan pariwisata bersumber dari wisata kuliner. Hal tersebut sangat berkaitan dengan beberapa penelitian dalam beberapa tahun terakhir ini, di mana pada tahun 2003 disebutkan bahwa $40 \%$ dari pembelanjaan yang dikeluarkan wisatawan adalah untuk makanan dan minuman (Boyne, Hall, \& William, 2003). Data pada tahun 2012 
menunjukkan bahwa kontribusi pendapatan pariwisata Amerika Serikat dari wisata gastronomi diperkirakan mencapai 52 miliar USD, sedang Inggris mencapai 8 miliar USD. Peluang tersebut menyebabkan UNWTO kemudian menempatkan wisata kuliner sebagai salah satu segmen yang sangat dinamis dalam pasar pariwisata global.

Karawang merupakan kabupaten yang bernilai sangat strategis bagi Indonesia. Karawang dikenal disamping sebagai sumber beras nasional, ternyata juga merupakan pemasok $90 \%$ air baku bagi masyarakat DKI Jakarta. Karawang ternyata memiliki potensi pariwisata utama berupa budaya dan sejarah, serta kuliner. Keragaman potensi ini perlu dikembangkan secara lebih sistematis untuk menjadikan Karawang sebagai destinasi pariwisata. Salah satu ikon pariwisata Karawang adalah Desa Walahar. Keberadaan Bendungan Citarum menjadi ikon yang mampu menjadi daya tarik untuk berkembangnya sektor ikutan lain. Penelitian ini didesain untuk menguji konsep ekosistem untuk diterapkan dalam pengembangan destinasi pariwisata.

\subsection{Eksosistem Pariwisata}

Konsep ekosistem pariwisata diinspirasi pertama kali dikemukakan oleh The Global Sustainable Tourism Council (GTSC) Criteria (2017) yang mengemukakan konsep ekosistem dalam rangka untuk mendapatkan pemahaman umum tentang pariwisata berkelanjutan, dan merupakan standar minimum yang harus dicapai oleh setiap usaha pariwisata.

\section{The Global Sustainable Tourism Council (GTSC) Criteria}

The Global Sustainable Tourism Council (GSTC) Criteria diciptakan dalam upaya untuk mendapatkan pemahaman umum tentang pariwisata berkelanjutan, dan merupakan standar minimum yang harus dicapai oleh setiap usaha pariwisata. Kriteria ini disusun dalam 4 (empat) tema utama, yaitu: (i) perencanaan keberlanjutan yang efektif, (ii) memaksimalkan manfaat sosial dan ekonomi bagi masyarakat setempat, (iii) meningkatkan warisan budaya, serta juga (iv) mengurangi dampak negatif terhadap lingkungan.

\section{Business Model Generation Canvas Model}

Business Model Generation Canvas Model ditulis oleh Alexander Osterwalder dan Yves Pigneur dan dibuat bersama 470 orang praktisi bisnis dari 45 negara. Model bisnis ini dipahami sebagai suatu model yang mampu menggambarkan dasar pemikiran tentang bagaimana organisasi menciptakan, memberikan dan menangkap nilai. Model bisnis ibarat cetak biru suatu strategi yang diterapkan melalui sembilan blok bangunan dasar yang mencakup empat bidang utama dalam bisnis, yaitu pelanggan, penawaran, infrastruktur dan kelangsungan finansial.

Pada model bisnis ini desain dan strategi menjadi sangat penting. Desain di sini adalah kemampuan "membayangkan sesuatu yang belum ada" dalam bisnis yang dihadapi. Sedangkan strategi dilihat sebagai upaya "menafsir ulang" yang akan membantu mempertanyakan secara konstruktif model bisnis yang sudah mapan dan mempelajari secara strategis lingkungan tempat model bisnis berfungsi.

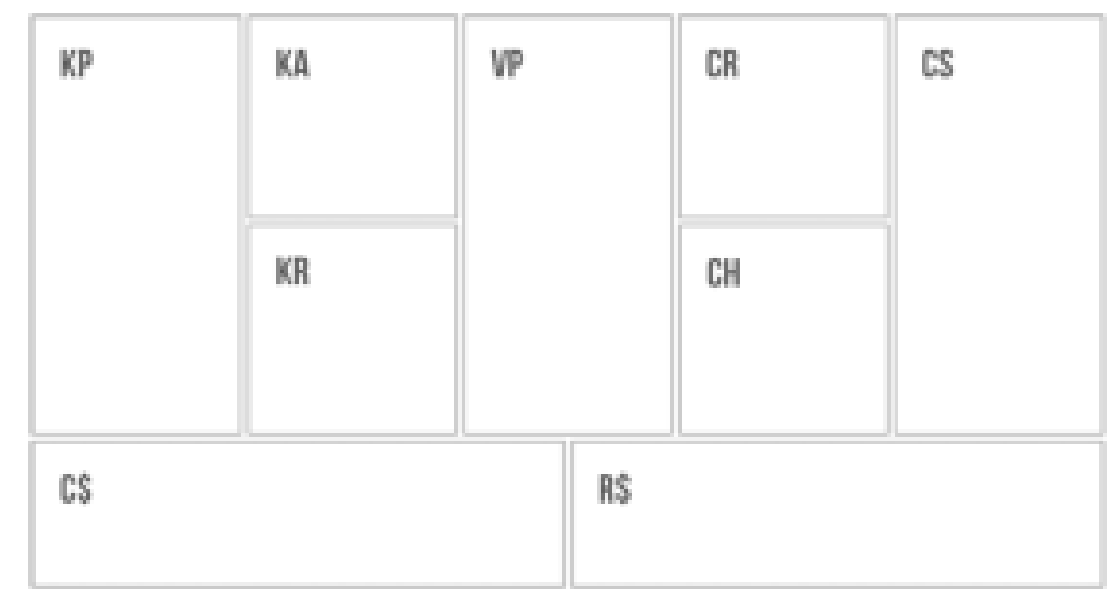

Gambar 1: Block Business Model Generation Canvas Model

Vincent Sylvester Leewellyn, Fitri Abdillah (Inventarisasi Konsep Ekosistem Pariwisata dalam Pengembangan...) 
Catatan:

1. CS: Customer Segments

2. VP: Value Propositions

3. $\mathrm{CH}$ : Channels

4. CR: Customer Relationship

5. R\$: Revenue Streams

6. KR: Key Resources

7. KA: Key Activities

8. KP: Key Partnership

9. CS: Cost Structures

Osterwalder \& Pigneur (2010) mengembangkan model kanvas untuk bisnis pariwisata dengan menguji model tersebut terhadap 470 orang praktisi bisnis dari 45 negara. Pada model ini, desain dan strategi menjadi komponen yang sangat penting. Desain di sini adalah kemampuan "membayangkan sesuatu yang belum ada" dalam bisnis yang dihadapi. Sedangkan strategi dilihat sebagai upaya "menafsir ulang" yang akan membantu mempertanyakan secara konstruktif model bisnis yang sudah mapan dan mempelajari secara strategis lingkungan tempat model bisnis berfungsi.

Konsep di atas kemudian dimodifikasi dengan menambahkan prinsip kesejahteraan masyarakat di dalamnya dan kemudian disebut sebagai Kanvas Model Bisnis Sosial. Model ini adalah pengembangan dari Business Model Generation Canvas Model yang memperhatikan prinsip penting dalam The Global Sustainable Tourism Council (GTSC) Criteria. Model ini menekankan perlunya desain dan strategi bisnis yang memberikan manf aat sosial bagi penduduk setempat pada suatu lingkungan bisnis. Pengembangan bisnis di sini tidak hanya antara barang dan jasa dengan pelanggan semata, tetapi juga memasukkan masyarakat sebagai penerima manfaat sosial. Model bisnis sosial ini dirumuskan agar masyarakat setempat tidak terpinggirkan dalam bisnis dan bahkan diposisi kan sebagai salah satu pelaku bisnis utama. Prinsip dari model ini adalah sebagai berikut.

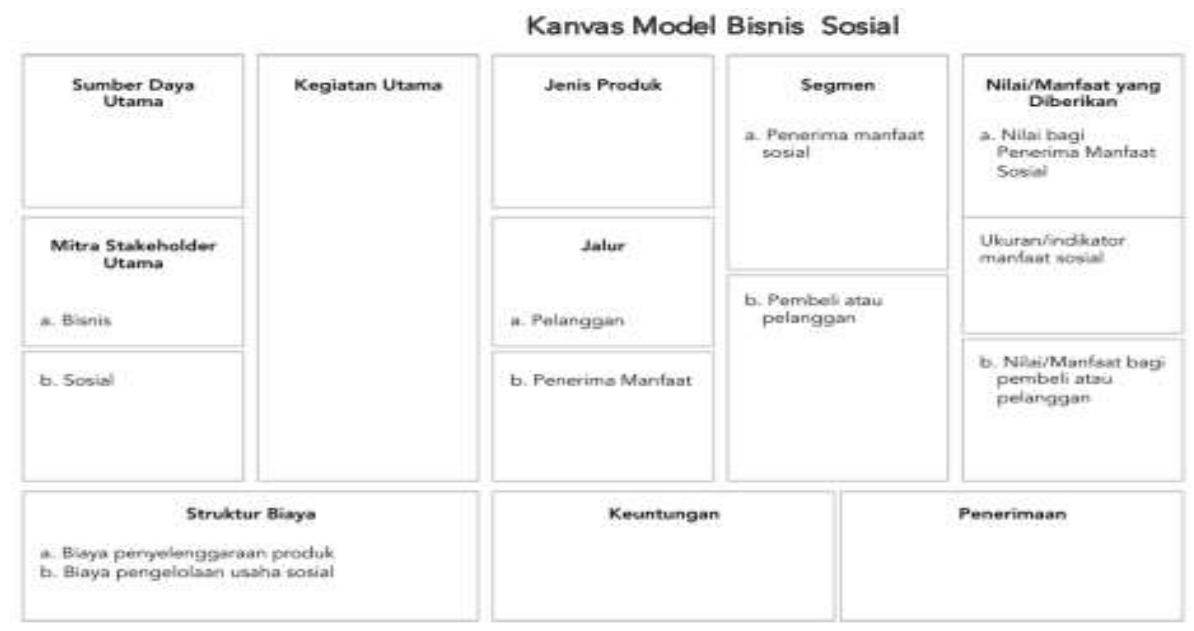

Gambar 2: Model Canvas Bisnis Sosial (Osterwalder \& Pigneur, 2010)

\subsection{Destinasi Pariwisata Kuliner}

Makanan merupakan faktor utama dalam pengembangan pariwisata namun seringkali diabaikan dalam banyak studi pariwisata. Permintaan terhadap makanan dalam pengembangan pariwisata terutama pariwisata makanan menunjukkan pertumbuhan yang signifikan. Namun demikian citra pariwisata makanan saat ini masih perlu pengakuan lebih pada dekade akhir ini, padahal di Australia dan Kanada, kuliner telah mampu menggerakkan ekonomi sebesar 1 milyar dolar per 
tahun. Angka tersebut merupakan angka yang sangat signifikan bagi pengembangan destinasi. Konsumsi makanan pada terminologi pariwisata saat ini telah berubah tidak hanya menjadi bagian integral dalam pengalaman berwisata, namun juga menjadi bagian dari penikmatan terhadap destinasi. Kuliner lokal adalah komponen fundamental dari atribut destinasi, menambah pengayaan atraksi, dan pengalaman wisata (Symons, 1999).

Berbagai usaha dilakukan pemerintah untuk mengembangkan potensi tersebut. Namun demikian nampaknya pengembangan kuliner sebagai atraksi pariwisata belum maksimal. Hal ini dapat dipahami oleh sebab konsep pembangunan destinasi pariwisata tidak didesain secara integratif dengan visi yang jelas untuk menjadikan Indonesia sebagai destinasi unggulan di dunia. Konsep ekosistem pariwisata dikembangkan untuk menjembatani terhentinya pemikiran tersebut. Destinasi pariwisata memerlukan konsep integratif yang mempertimbangkan faktor demand and supply serta carrying capacity. Konsep ekosistem ini diharapkan dapat menjadi model pengembangan destinasi pariwisata di Indonesia khususnya destinasi kuliner.

Keterkaitan makanan dan destinasi pariwisata saat ini telah berkembang tidak hanya sebagai produk kebutuhan dasar oleh wisatawan, akan tetapi juga sudah digunakan sebagai pembeda destinasi dengan menciptakan suasana yang mengesankan. Hal ini kemudian menjadi identitas destinasi. Makanan juga bisa menambah nilai produk pariwisata inti dan menjadi fokus untuk acara khusus. Selain itu makanan bisa digunakan untuk menarik ceruk pasar tertentu yang jumlahnya sedikit namun biasanya memiliki selera yang tinggi dan sanggup mengeluarkan uang dalam jumlah yang besar.

(David \& Tozser, 2009) menjelaskan destinasi pariwisata sebagai lokasi fisik tempat wisatawan meluangkan waktu minimal satu malam di tempat tersebut. Lokasi tersebut memiliki atraksi wisata, produk dan layanan yang diperlukan oleh para wisatawan selama tinggal. Destinasi pariwisata memiliki keterbatasan fisik dan administratif, yang ditentukan oleh pengelolaannya serta memiliki citra dan persepsi sebagai daya tarik bagi wisatawan. Dalam konsep ini destinasi pariwisata dipandang sebagai ruang untuk terciptanya interaksi antara wisatawan dan masyarakat lokal (host and guest).

Untuk menjadi sebuah destinasi pariwisata, suatu lokasi atau wilayah harus memenuhi beberapa faktor determinan yang penting (Buhalis, 2000) sebagai berikut:

a) Atraksi wisata, seperti faktor alam dan faktor yang dibuat manusia seperti warisan, budaya, event khusus dan sebagainya.

a) Keterjangkauan, yaitu sistem lalulintas terpadu termasuk di dalamnya jalan, petunjuk jalan, alat transportasi dan sebagainya.

b) Pelayanan wisatawan, seperti akomodasi, restoran dan sebagainya.

c) Paket produk, segala aktivitas yang dapat dilakukan oleh wisatawan selama tinggal seperti pelayanan publik, bank, telekomunikasi dan sebagainya.

Berbasis pemahaman diatas (Ignatov \& Smith, 2006) menyusun definisi pariwisata kuliner sebagai berikut, 'selama berwisata, wisatawan melakukan baik (i) membayar dan menikmati makanan lokal, (ii) observasi dan menyelidiki proses produksi makanan (dari petani ke sekolah memasak), dan menjadikan hal ini sebagai motivasi perjalanan wisata atau aktivitas perjalanan wisata yang paling penting'. Pariwisata kuliner juga meningkatkan kesadaran diri wisatawan melalui perjalanan wisata ke destinasi pariwisata melalui makanan, yang tentu saja sangat berbeda dengan sekadar mengkonsumsi makanan sebagaimana perjalanan wisata biasa.

Dalam konteks peran makanan dalam pariwisata, (Hall \& Mitchell, 2005) menyusun katagori berdasarkan motivasi dan perilaku wisatawan dalam menikmati makanan dan tempat menikmatinya. 


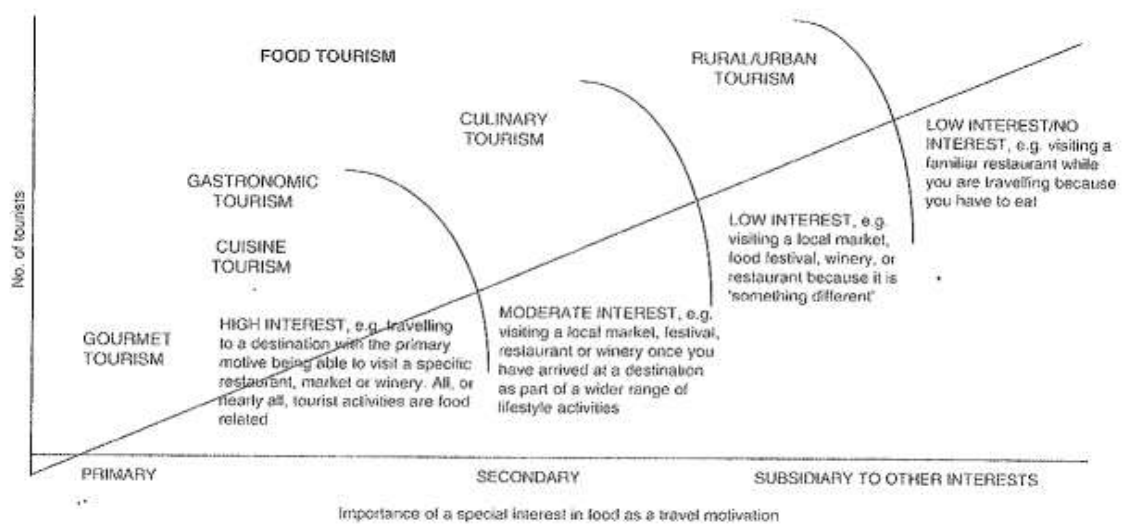

Gambar 3: Kategorisasi Food Tourism berdasar Motivasi dan Jumlah Wisatawan

Dari gambar di atas Hall and Mitchell ingin menyampaikan bahwa food tourism dapat dikategorikan dengan menggunakan tingkat interest wisatawan berkunjung dan jumlah wisatawan. Interes wisatawan dibagi dalam tiga kategori yaitu primer, sekunder, dan tersier.

\subsection{Kerangka Pikir Implementasi}

Kerangka pikir penelitian ini disusun dengan melakukan modifikasi dari model di atas dan disusun menjadi model ekosistem baru sebagai berikut.
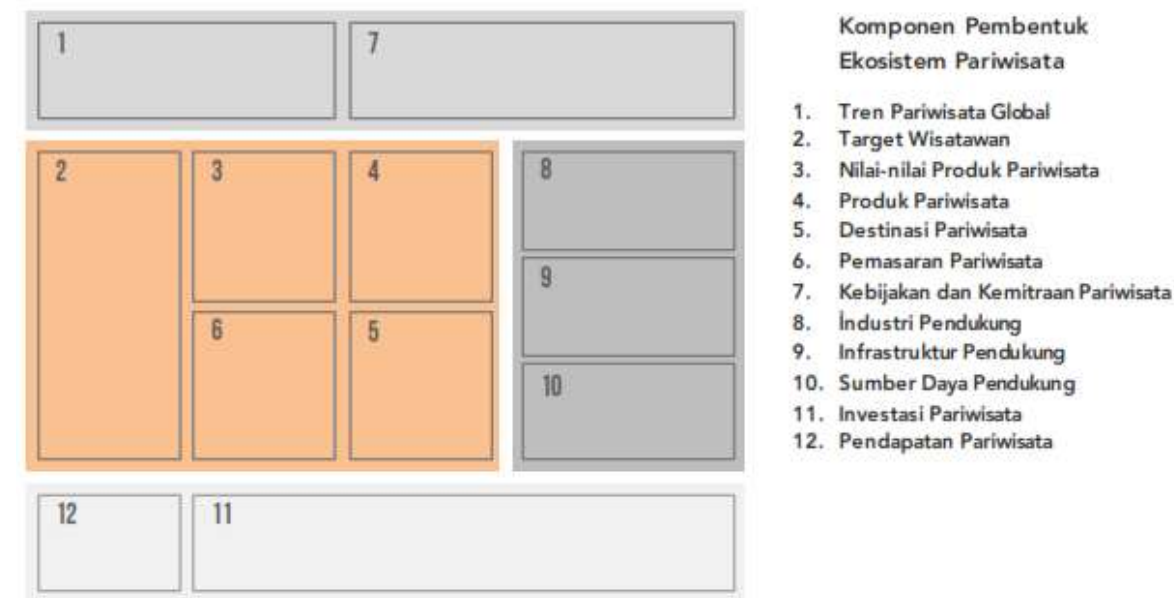

Gambar 3: Kerangka Pikir - Model Ekosistem Pariwisata

Model ekosistem pariwisata ini meliputi 12 (dua belas) komponen pembentuk yang terbagi dalam 4 (empat) sub-ekosistem seperti tergambarkan sebagai berikut ini.

b) Sub-ekosistem Utama

c) Sub-ekosistem Pendorong

d) Sub-ekosistem Pendukung

e) Sub-ekosistem Bisnis

\subsection{Permasalahan}

Permasalahan pengembangan pariwisata setidaknya diidentifikasi bahwa Desa Walahar memiliki potensi pengembangan daya tarik wisata yang dapat dioptimalkan menjadi atraksi pariwisata sehingga memiliki potensi investasi untuk pengembangan pariwisata terutama kuliner. Namun demikian potensi pengembangan kuliner belum dapat dioptimalkan sebagai atraksi wisata yang mampu menarik kunjungan wisatawan sehingga berkontribusi maksimal terhadap pembangunan desa dan wilayah. Konsep ekosistem pariwisata memaparkan tentang keterkaitan 
berbagai komponennya sebagai bagian dari pengembangan destinasi pariwisata berkelanjutan. Saat ini belum dapat diidentifikasi profil komponen-komponen ekosistem yang terlibat dalam pengembangan Walahar sebagai destinasi wisata kuliner.

\subsection{Tujuan Penelitian}

Berdasarkan permasalahan diatas, tujuan penelitian ini adalah menginventarisir profil komponen-komponen eksosistem pariwisata yang terlibat dalam pengembangan Walahar sebagai destinasi wisata kuliner.

\section{Metode Penelitian}

Penelitian ini dilaksanakan di Desa Walahar, Kecamatan Klari, Kabupaten Karawang. Desain penelitian ini adalah desain Research dan Action Research dimana temuan yang diperoleh akan dimplementasikan dalam rencana aksi untuk mewujudkan luaran penelitian (Sekaran, 2010). Pada tahap ini penelitian dilakukan adalah menginventaris 12 komponen ekosistem sesuai dengan model hipotetis yaitu: Tren Pariwisata Global, Target Wisatawan, Nilai Produk, Produk Wisata, Destinasi Wisata, Pemasaran Pariwisata, Kebijakan Pengembangan Wisata, Industri Pendukung, Fasilitas Pendukung, Sumberdaya Pariwisata, Investasi Pariwisata, dan Penerimaan Masyarakat. Pengumpulan data dilakukan dengan observasi lapangan dan wawancara pada beberapa informan masyarakat di sekitar Waduk Walahar. Data dianalisis dengan sortasi informasi dan deskripsi terhadap poin-poin hasil wawancara yang dilakukan.

\section{Pembahasan}

\subsection{Profil Desa Walahar}

Desa Walahar terletak di Kecamatan Klari, Kabupaten Karawang, Provinsi Jawa Barat. Terletak di bagian Selatan dari Jalan Raya Pantura dan bagian Utara Sungai Citarum serta Desa Waringin. Desa Walahar memiliki luas wilayah sebesar kurang lebih 280 hektare. Desa Walahar terhubung dengan Desa Waringin melalui Bendungan Walahar.

Jumlah penduduk Desa Walahar pada tahun 2018 sebanyak 8.091 jiwa dengan persentase untuk laki-laki sebanyak $47,92 \%$ dan untuk perempuan sebesar $52.08 \%$. Namun jumlah penduduk ini menurun sebesar $1.2 \%$ bila dibandingkan dengan jumlah penduduk pada tahun 2017 yang sebesar 8.188 jiwa. Sebaran umur penduduk Desa Walahar yang paling banyak termasuk dalam kategori usia produktif, yakni pada rentang umur 17-60 tahun, sebesar $69.93 \%$. Sedangkan untuk usia pelajar dan balita sebesar $21,95 \%$ dan untuk usia pensiunan (60 tahun keatas) yaitu sebesar $8,12 \%$. Untuk masing-masing rentang usia, perbandingan antara jenis kelamin laki-laki dan perempuan relatif sama.
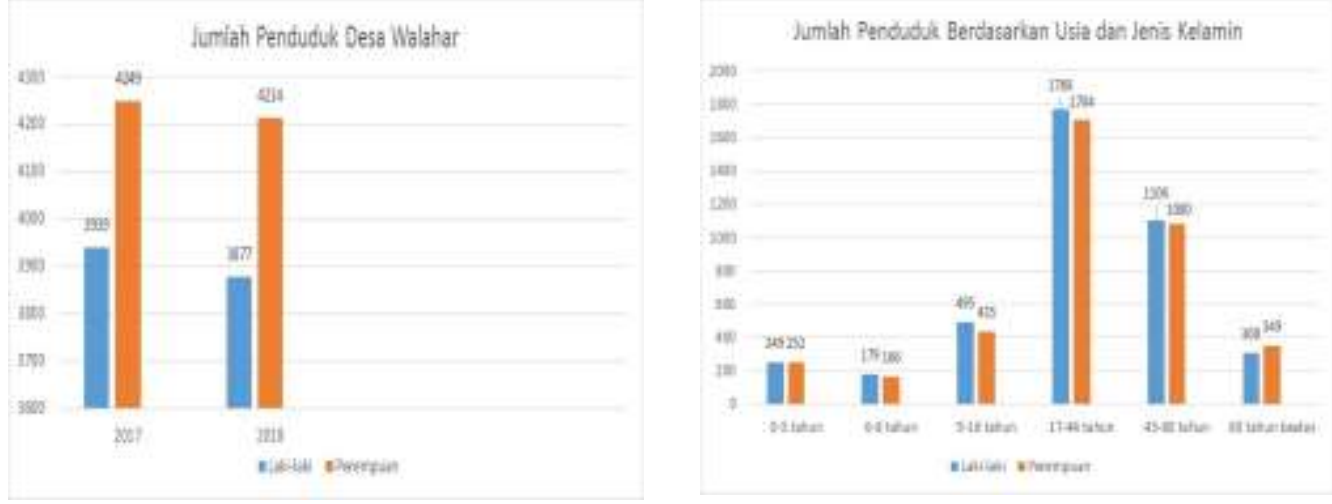

Sumber : https://walahar.desa.id/. 2018

Gambar 4: Kerangka Pikir - Model Ekosistem Pariwisata 
Berdasarkan data, mata pencaharian penduduk Desa Walahar yang paling banyak adalah bekerja sebagai karyawan perusahaan/buruh yakni sebesar 41,28\% dari jumlah penduduk 2018. Jumlah penduduk paling banyak kedua adalah sebagai pemilik penginapan dan wirausahawan adalah sebanyak 5,994\%. Untuk pekerjaan sebagai petani pemilik sawah dan buruh tani di Desa Walahar sebesar 2,25\%. Namun dari 8.091 jiwa penduduk Desa Walahar, hanya 4.550 jiwa atau sebesar $56,24 \%$ saja yang bekerja. Sedangkan, sebanyak 2.433 jiwa atau sebesar 30,07\% tidak bekerja karena termasuk ke dalam umur balita, pelajar, serta pensiunan. Sisanya, sebesar 1.108 jiwa atau sebesar 13,69\% penduduk Desa Walahar termasuk ke dalam kategori pengangguran.

\subsection{Potensi Wisata Desa Walahar}

Potensi wisata yang dimiliki oleh Desa Walahar sebagai destinasi pariwisata adalah sebagai berikut.

a) Waduk Walahar

Bendungan Walahar merupakan bendungan yang terletak di Walahar, Klari, Karawang, Jawa Barat. Bendungan ini merupakan salah satu bangunan peninggalan masa penjajahan Belanda yang masih ada dan kokoh berdiri di Karawang. Bendungan Walahar digunakan untuk mengatur debit air sungai Citarum serta mengairi sawah-sawah yang berada di Kabupaten Karawang seluas 87.396 hektare. Bendungan Walahar membentuk waduk seluas \pm 15 hektare. Bendungan ini berbatasan dengan Gintung Kerta di sebelah utara, Anggadita di sebelah barat, Kutapuhaci di sebelah selatan, dan sebelah timur berbatasan dengan Cimahi.

Proyek pembangunan Bendungan Walahar ini dimulai pada tahun 1923 oleh Belanda dengan pengawasan seorang ahli perairan dari Belanda bernama C. Swaan Koopman. Bendungan Walahar mulai dipakai pada tanggal 30 November 1925. Bendungan ini dibangun melintang pada aliran Sungai Citarum sehingga membendung sungai tersebut seluas \pm 50 meter. Bangunan bendungan terdiri dari 3 bagian, yaitu bagian bawah, yang merupakan pintu penahan air yang berjumlah 5 pintu; bagian kedua merupakan jembatan seluas 3 meter, yang menghubungkan Klari dan Anggadita; dan bagian ketiga merupakan ruang mesin untuk mengatur sistem bendungan. Pintu bendungan Walahar pernah direnovasi pada tahun 1989 dan pada tahun 2009.

Bendungan Walahar berfungsi sebagai pengatur debit air sungai Citarum serta mengairi areal persawahan seluas 87.396 hektare yang berada di Kabupaten Karawang. Selain itu, bendungan dipakai untuk menahan air bagi penduduk di Karawang bagian utara ketika musim hujan tiba. Bendungan ini digunakan pula sebagai sarana rekreasi, lokasi memancing, serta lokasi wisata. Fasilitas yang sudah ada di bendungan ini untuk menunjang wisatawan adalah:

a. Area Parkir kendaraan

b. Mushola

c. Kamar mandi/MCK

d. Penginapan

e. Dan masih banyak lainya

\section{b) Kuliner}

Desa Walahar memiliki potensi kuliner yang khas dan tidak terdapat di wilayah lainnya adalah pepes patin (Pangasius pangasius var.). Oleh penduduk sekitar Walahar, patin dikatakan juga sebagai jambal roti. Pepes adalah cara memasak ikan dengan cara dikukus dengan membungkus ikan setelah dilumuri bumbu dan rempah-rempah selama kurang lebih 3 jam hingga duri ikan menjadi lunak. Saat ini jenis-jenis pepes tidak hanya patin, namun telah berkembang dengan ikan mas, ikan teri, oncom, jamur, tahu, dan ayam. Tidak tertutup kemungkinan jenis makanan lain untuk dipepes mengingat di Waduk Walahar masih terdapat beberapa jenis ikan lain yang belum dicoba untuk dipepes. Saat ini ada dua warung yang secara viral telah dikenal oleh masyarakat lokal. 
Jenis makanan lain yang unik adalah keong air tawar (Filopaludina javanica). Nilai keunikan makanan ini adalah dengan diiisap setelah ujung cangkang dipecahkan terlebih dahulu. Hanya beberapa warung kecil yang menyediakan jenis makanan ini.

\section{c) Suvenir}

Potensi wisata lain di Desa Walahar adalah adanya kerajinan enceng gondok (Eichornia Crassipes). Eceng gondok merupakan gulma air yang sering bikin gondok para petani, karena tumbuh di sawah berebut unsur hara dengan tanaman budidaya (padi). Tanaman asal Brasil yang didatangkan oleh Kebun Raya Bogor pada tahun 1894, dan merupakan tanaman hias yang digemari karena bunganya yang berwarna ungu sangat menarik.

Kehadiran Eceng Gondok kemudian menjadi hama dan menutupi perairan. Eceng gondok yang pada mulanya hanya dikenal sebagai tanaman gulma air, karena pertumbuhannya yang begitu cepat sehingga menutupi permukaan air, dan menimbulkan dampak penurunan kualitas air. Bendungan Walahar dan daerah aliran sungai (DAS) lainnya di wilayah Kabupaten Karawang terdampak pertumbuhan yang sangat cepat tersebut. Namun demikian di lain sisi Eceng gondok juga memberikan nilai tambah yang prospektif. Salah satu pemanfaatan enceng gondok yang menarik adalah menjadikannya kerajinan tangan.
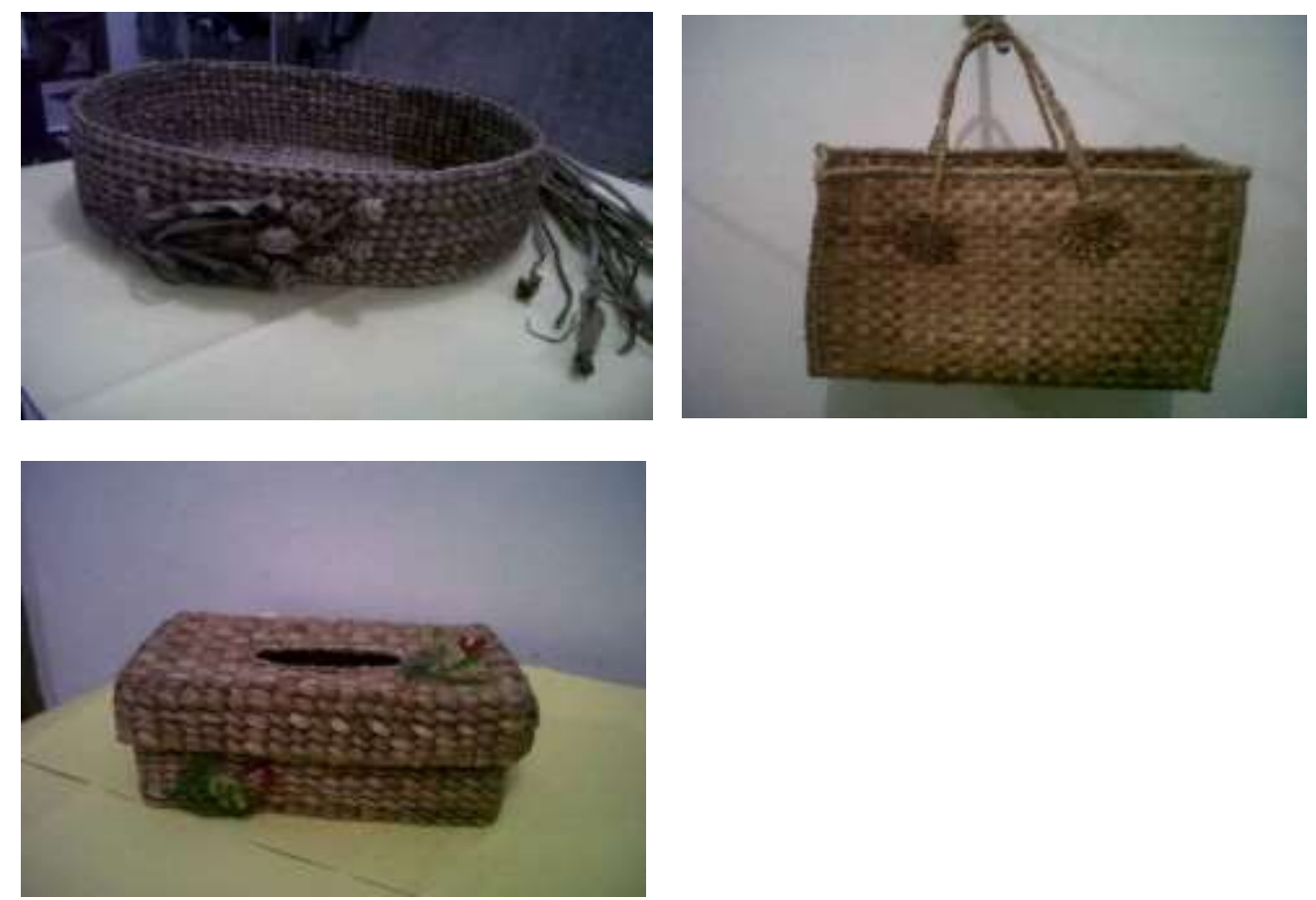

Sumber: https://www.faktajabar.co.id/di-karawang-eceng-gondok-ternyata-bisa-hasilkan-uang/

Gambar 5: Suvenir Industri Enceng Gondok

\subsection{Profil Komponen-Komponen Ekosistem Pariwisata Kuliner di Walahar}

Pengembangan eksosistem ini dilakukan melalui observasi awal tentang kondisi eksisting Desa Walahar sebagai destinasi pariwisata kuliner. Hasil observasi tentang 12 komponen eksosistem menunjukkan hasil sebagai berikut. 


\begin{tabular}{|c|c|c|}
\hline No & Desain Subsistem & Deskripsi \\
\hline 1 & Tren Pariwisata Global & $\begin{array}{l}\text { Walahar berkembang secara tradisional dan tidak pernah } \\
\text { terpengaruh oleh perubahan lingkungan global secara langsung. } \\
\text { Perubahan lingkungan global secara tidak langsung berpengaruh } \\
\text { terhadap daya beli masyarakat. }\end{array}$ \\
\hline 2 & Target Wisatawan & $\begin{array}{l}\text { Meskipun telah ditetapkan sebagai kawasan wisata (Perda No } 2 \\
\text { Karawang tentang RTRW) namun pengembangan kawasan belum } \\
\text { secara serius dilakukan. Wisatawan yang datang masih merupakan } \\
\text { wisatawan lokal yang sekedar singgah untuk menikmati udara segar } \\
\text { dan makan. }\end{array}$ \\
\hline 3 & Nilai Produk & $\begin{array}{l}\text { Nilai produk yang ditawarkan masih merupakan nilai kelokalan } \\
\text { murni. Belum ada sentuhan kreativitas atau teknologi dalam } \\
\text { mengemas sebagian besar produk wisata. Namun demikian } \\
\text { kerajinan souvenir telah menerapkan teknologi dan pemasaran untuk } \\
\text { mengembangkan produknya. }\end{array}$ \\
\hline 4 & Produk Wisata & $\begin{array}{l}\text { Produk yang berpotensi menjadi ikon pawisata yang teridentifikasi } \\
\text { dalam jumlah yang cukup banyak (lebih dari 10) didominasi kuliner. } \\
\text { Namun demikian belum ditemukan nilai tambah yang signifikan } \\
\text { kecuali kerajinan souvenir yang secara umum masih mengandalkan } \\
\text { pasar di luar Karawang. }\end{array}$ \\
\hline 5 & Destinasi Wisata & $\begin{array}{l}\text { Walahar sebagai destinasi pariwisata masih dikelola secara otodidak } \\
\text { dan tradisional. Penataan amenitas masih memerlukan perhatian. } \\
\text { Akses sudah cukup baik namun belum ditemukan atraksi wisata } \\
\text { yang mendukung potensi yang ada. }\end{array}$ \\
\hline 6 & Pemasaran Pariwisata & $\begin{array}{l}\text { Marketing dilakukan dengan tidak terorganisasi meskipun Karawang } \\
\text { telah menetapkan Walahar sebagai destinasi unggulan }\end{array}$ \\
\hline 7 & $\begin{array}{l}\text { Kebijakan } \\
\text { Pengembangan Wisata }\end{array}$ & $\begin{array}{l}\text { Belum ada kebijakan khusus yang mengatur Walahar sebagai } \\
\text { destinasi pariwisata. }\end{array}$ \\
\hline 8 & Industri Pendukung & $\begin{array}{l}\text { Industri pendukung pariwisata banyak terdapat di sekitar Kota } \\
\text { Karawang namun belum diarahkan untuk pengembangan destinasi } \\
\text { pariwiata. Di Walahar terdapar beberapa industry pendukung seperti } \\
\text { enceng gondok, pepes ikan, dan beberapa industry kerajinan. }\end{array}$ \\
\hline 9 & Fasilitas Pendukung & $\begin{array}{l}\text { Infrastruktur yang ada sangat mendukung pengembangan destinasi. } \\
\text { Kedekatan Walahar dengan pusat kota dan jalan provinsi menuju } \\
\text { Purwakarta menyebabkan infrastruktur jalan terpelihara dengan } \\
\text { baik. }\end{array}$ \\
\hline 10 & Sumberdaya Pariwisata & $\begin{array}{l}\text { Sumberdaya pendukung pariwisata nampaknya masih perlu } \\
\text { ditingkatkan kualitasnya. }\end{array}$ \\
\hline 11 & Investasi & $\begin{array}{l}\text { Belum ada investasi yang cukup besar untuk menggerakkan } \\
\text { ekonomi masyarakat }\end{array}$ \\
\hline 12 & Penerimaan Masyarakat & $\begin{array}{l}\text { Belum ada penerimaan yang secara eksplisit terhadap perekonomian } \\
\text { lokal selain sektor informal berupa warung-warung yang ada di } \\
\text { sekitar waduk }\end{array}$ \\
\hline
\end{tabular}

Sumber: observasi lapang, 2018

Dari tabel diatas dapat dilihat bahwa pengembangan Walahar sebagai destinasi memerlukan effort yang signifikan dan keseriusan pemerintah. Potensi yang dimiliki merupakan aset yang dapat dikembangkan.

Dari 12 subsistem eksosistem nampaknya Walahar hanya siap dalam hal produk wisata yang dimiliki yaitu kuliner dan daya tarik wisata. Produk kuliner sudah sangat siap untuk dikembangkan dengan memberikan nilai tambah minimal berupa brand dan pengemasaan produk sehingga dapat menjadi suvenir. Tingkat higienitas produk nampaknya juga perlu ditingkatkan untuk memberi jaminan konsumen menikmati produk tanpa ada khawatir dampaknya. Dalam hal daya tarik wisata, secara alami Walahar telah memiliki modal yang sangat lengkap sebagai daya tarik. Pemandangan alam yang ada merupakan jaminan leisure yang sangat baik untuk kesehatan. 
Sejarah Walahar yang panjang merupakan modal utama penyajian informasi destinasi (story telling). Dalam hal daya tarik wisata nampaknya Walahar paling siap dibandingkan dengan sub sistem lainnya.

\subsection{Pengelolaan Limbah}

Sebagaimana berbagai kegiatan pembangunan dan pengembangan pada umumnya, pengembangan pariwisata di suatu wilayah pasti juga akan menimbulkan dampak terhadap lingkungan sekitarnya. Oleh karena itu, maka pengelolaan lingkungan juga harus mendapat perhatian penting mulai dari tahap awal, termasuk pada saat perencanaan pengembangan pariwisata di Desa Walahar. Aspek-aspek pengelolaan lingkungan yang perlu mendapat perhatian terkait pengembangan pariwisata di desa Walahar khususnya:

a) Pengelolaan limbah cair dan limbah padat (sampah) dari rumah warga, penginapan (hotel, homestay, dan sebagainya), dan juga dari usaha kuliner (rumah makan, produksi makanan/camilan, dan sebagainya).

b) Pengelolaan kualitas lingkungan sungai/bendungan walahar dan bantaran sungainya.

c) Peningkatan pemahaman dan kesadaran masyarakat akan pentingnya pengelolaan lingkungan.

d) Penataan tata ruang dan peruntukan area di kawasan wisata beserta area sekelilingnya.

Aspek-aspek tersebut perlu direncanakan dan diantisipasi sejak awal karena dari pengamatan di berbagai lokasi wisata selama ini diketahui bahwa berkembangnya suatu lokasi wisata memiliki potensi untuk menimbulkan dampak negatif, antara lain:

a) Banyak wisatawan yang masih suka/cenderung membuang sampah sembarangan (mengotori lokasi wisata).

b) Berkontribusi terhadap pencemaran badan air dan area di sekitarnya.

c) Berkembangnya pembangunan yang tidak diinginkan.

d) Gangguan dan kerusakan pada flora dan fauna setempat.

Kondisi saat ini di desa Walahar untuk ketiga aspek tersebut dapat dikatakan masih sangat kurang dan masih membutuhkan banyak upaya perbaikan di keempat aspek tersebut di atas. Beberapa upaya yang dapat dilakukan untuk menangani aspek-aspek tersebut di antaranya adalah melalui:

a) Perencanaan dan pembangunan instalasi pengolahan air limbah terdesentralisasi, baik untuk pemukiman penduduk maupun untuk penginapan dan usaha kuliner.

b) Kampanye/edukasi untuk warga masyarakat maupun para pendatang/wisatawan terkait pengelolaan lingkungan kawasan sungai citarum dan bendungan walahar beserta bantarannya.

c) Edukasi untuk anak-anak sekolah. Ibu-ibu, dan para pelaku usaha yang ada di wilayah walahar.

d) Pembuatan kajian yang update untuk tata ruang dan peruntukan lahan disesuaikan dengan rencana pengembangan wisata di kawasan walahar.

\section{Kesimpulan dan Saran}

Beberapa simpulan yang dapat dikemukakan adalah sebagai berikut:

1. Dari dua belas komponen ekosistem yang ditelaah nampaknya Walahar memerlukan upaya serius untuk menciptakan destinasi kuliner di Karawang.

2. Pendekatan integrative ecosystem pariwisata memerlukan bimbingan teknis dalam penyamaan persepsi. Pemetaan program pengembangan destinasi kuliner memerlukan effort yang signifikan dan keseriusan pemerintah.

3. Studi seharusnya dipadukan dengan pengelolaan lingkungan dengan meningkatkan kualitas lingkungan dengan kesadaran peningkatan sanitasi dan higenne kuliner dan lingkungan. 
Saran yang dapat dikemukakan adalah perlunya penyadaran masyarakat tentang produk dan value pariwisata yang harus diciptakan dalam rangka mempersiapkan Walahar sebagai destinasi unggulan.

\section{Referensi}

Buhalis, D. Marketing the Competitive Destination of the Future. Tourism Management. 2000. 115.

David, L., \& Tozser, A. Destination Management: Necessity And Tasks Of Tourism Destination Management In Hungary. Applied Studies in Agribusiness and Commerce, Vol. 3, No.6. 2009. 81-84.

Hall, C., \& Mitchell, R. Gastronomic tourism: Comparing food and wine tourism experiences. In M. N. (Ed.), Niche tourism, contemporary issues, trends and cases (pp. 89-100 ). Boston: Elsevier, Barking. 2005.

Ignatov, E., \& Smith, S. Segmenting Canadian Culinary Tourists. Current Issues in Tourism, 9 (3). 2006. 235-255.

Inskeep, E. Tourism planning: an integrated and sustainable development approach. New York: Van Nostrand Reinhold. 1991.

Osterwalder, A. \& Pigneur, Y. Business Model Generation. 2010.

Sekaran, U. Research Methods for Business. New York: John Wiley and Sons. 2003.

Symons, M. Gastronomic Authenticity and The Sense of Place. 9th Australian Tourism and Hospitality Research Conference for Australian University Tourism and Hospitality Education. Melbourne: Australian University Tourism and Hospitality Education. 1999. pp. 1-12.

The Global Sustainable Tourism Council (GTSC) Criteria. 2017.

United Nations World Tourism Organization. Second Global Report on Gastronomy Tourism. UNWTO. 2017. https://doi.org/10.2791/284013.

Undang-Undang No. 10 Tahun 2009 tentang Kepariwisataan. 